\title{
Tandem palladium-catalyzed borylation and Suzuki coupling (BSC) to thienocarbazole precursors
}

\author{
Isabel C. F. R. Ferreira, ${ }^{a}$ Maria-João R. P. Queiroz ${ }^{\mathrm{a}, *}$ and Gilbert Kirsch ${ }^{\mathrm{b}}$ \\ a Departamento de Química, Universidade do Minho, 4710-057 Braga, Portugal \\ ${ }^{\mathrm{b}}$ Laboratoire d'Ingénierie Moleculaire et Biochimie Pharmacologique, Université de Metz, Faculté des Sciences, Ile du Saulcy, \\ 57045 Metz, France
}

Received 25 February 2003; accepted 15 April 2003

\begin{abstract}
Substituted 2-methyl-2'-nitro diaryl compounds in the benzo[ $b]$ thiophene series were prepared by palladium-catalyzed, two-step, one-pot borylation/Suzuki coupling (BSC) reaction in good to high yields. The borylation reaction was performed on methylated 6-bromobenzo[b]thiophenes using pinacolborane and was followed by in situ Suzuki coupling with substituted $\left(\mathrm{CF}_{3}\right.$, $\mathrm{OMe}$ ) 2-bromonitrobenzenes. The compounds obtained were cyclized to the corresponding ring A substituted thienocarbazoles which can have biological activity or/and be used as biomarkers due to their fluorescence properties and possible DNA intercalation. (C) 2003 Elsevier Science Ltd. All rights reserved.
\end{abstract}

\section{Introduction}

The synthesis of heteroannellated carbazoles continues to attract a lot of interest due to the expected biological activity of these products. Thienocarbazoles, bioisosteres of the natural anti-tumor pyridocarbazoles (ellipticine and olivacine), are interesting targets not only for biological activity but also to be used as biomarkers due to their fluorescence properties ${ }^{1}$ and possible DNA intercalation. We have already developed several convergent ring $\mathrm{B}$ routes for the synthesis of methylated thienocarbazoles by intramolecular cyclization of precursors obtained either by $\mathrm{C}-\mathrm{C}^{2}$ or $\mathrm{C}-\mathrm{N}^{3}$ palladium or copper-catalyzed cross couplings.

In the $\mathrm{C}-\mathrm{C}$ cross coupling route we have described the synthesis of nitro precursors of ring A unsubstituted thienocarbazoles from bromobenzo $[b]$ thiophenes by a one-pot, three-step reaction (bromine-lithium exchange, boron transmetalation and Suzuki coupling) in moderate yields. ${ }^{2}$

We report here an improved synthesis of nitro precursors of ring A substituted $\left(\mathrm{CF}_{3}, \mathrm{OMe}\right)$ thienocarbazoles

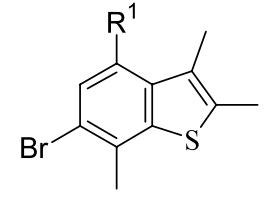

1. Borylation

2. Suzuki coupling

$$
\begin{aligned}
\text { 1a } R^{1} & =H \\
1 b R^{1} & =M e
\end{aligned}
$$

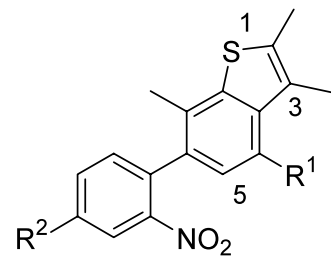

$$
\begin{aligned}
& \text { 2a } R^{1}=H, R^{2}=O M e(80 \%) \\
& \text { 2b } R^{1}=H, R^{2}=C_{3}(70 \%) \\
& \text { 2c } R^{1}=M e, R^{2}=C F_{3}(50 \%)
\end{aligned}
$$

Scheme 1. Reagents and conditions: (1) pinacolborane, $\mathrm{Pd}(\mathrm{OAc})_{2}, 2-\left(\right.$ dicyclohexylphosphino)biphenyl, $\mathrm{Et}_{3} \mathrm{~N}, \mathrm{dioxane}^{1} \mathrm{~h}, 80^{\circ} \mathrm{C}$; $(2)$ 2-bromonitrobenzene, $\mathrm{H}_{2} \mathrm{O}, \mathrm{Ba}(\mathrm{OH})_{2} \cdot 8 \mathrm{H}_{2} \mathrm{O}, 1 \mathrm{~h}, 100^{\circ} \mathrm{C}$ (see Ref. 5). 
$2 a, 2 b$ or $2 c$

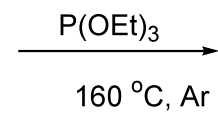

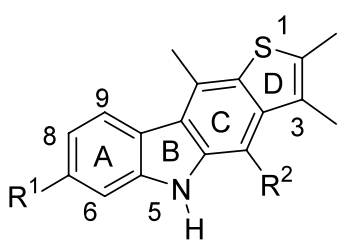

3a $R^{1}=$ OMe, $R^{2}=H, 70 \%$

3b $\mathrm{R}^{1}=\mathrm{CF}_{3}, \mathrm{R}^{2}=\mathrm{H}, 40 \%(\mathrm{~N}-\mathrm{Et}, 10 \%)$

$3 \mathbf{b} \mathrm{R}^{1}=\mathrm{CF}_{3}, \mathrm{R}^{2}=\mathrm{Me}, 60 \%$

Scheme 2. Reductive cyclization to thienocarbazoles 3 (see Ref. 7).

by palladium-catalyzed, two-step, one-pot borylation/ Suzuki coupling (BSC) reaction ${ }^{4}$ in good to high yields $(50-80 \%)$. To our knowledge it is the first time that this methodology is applied to the synthesis of 2-methyl-2'nitro biaryls.

\section{Results and discussion}

Tri- or tetramethylated 6-bromobenzo[b]thiophenes 1a or $\mathbf{1 b}$ were boronated using pinacolborane and this was followed by in situ Suzuki coupling with substituted $\left(\mathrm{CF}_{3}, \mathrm{OMe}\right)$ 2-bromonitrobenzenes (Scheme 1). The nature of the substituents ortho to the bromine atoms on both aromatic rings, methyl as EDG on the component to be boronated and nitro as EWG on the coupling component, proved to be suitable for this reaction and in agreement with the rules postulated by others. ${ }^{4}$

The yield obtained in the synthesis of compound $\mathbf{2} \mathbf{c}$ is probably due to the lower reactivity of compound $\mathbf{1 b}$ as we have already noticed in $\mathrm{C}-\mathrm{N}$ coupling reactions. ${ }^{6}$

The nitro compounds 2 were then cyclized to the corresponding new linear thienocarbazoles $\mathbf{3}$ in moderate to good yields, using triethylphosphite as shown in Scheme 2.

In the synthesis of $\mathbf{3 a}$ and $\mathbf{3 b}$ only vestiges of the N-Et compounds were observed in the ${ }^{1} \mathrm{H}$ NMR of the crude mixtures. The $\mathrm{N}-\mathrm{Et}$ derivative of $\mathbf{3 b}$ was isolated in $10 \%$ yield, lowering the yield of the $\mathrm{N}-\mathrm{H}$ compound.

\section{Conclusion}

We have applied the BSC reaction to the synthesis of new 2-methyl-2'-nitro biaryl precursors of tetracyclic heteroaromatic systems which can have biological activity and/or can be used as biomarkers. This reaction proved to be compatible either with additional electron donating $(\mathrm{OMe})$ or withdrawing $\left(\mathrm{CF}_{3}\right)$ groups which are known by their importance in the solubility of the molecules and in biological activities.

\section{Acknowledgements}

Thanks are due to the Foundation for Science and
Technology, IBQF, University of Minho (Portugal), to the Research Incitment Programme of the Calouste Gulbenkian Foundation (Portugal) for financial support and to the Escola Superior Agrária, Instituto Politécnico de Bragança for supporting in part I.C.F.R.F. (Ph.D.).

\section{References}

1. Seixas de Melo, J.; Rodrigues, L. M.; Serpa, C.; Arnaut, L. G.; Ferreira, I. C. R. F.; Queiroz, M.-J. R. P. Photochem. Photobiol. 2003, 77, 121-128.

2. Ferreira, I. C. F. R.; Queiroz, M.-J. R. P.; Kirsch, G. J. Heterocyclic Chem. 2001, 38, 749-754.

3. Ferreira, I. C. F. R.; Queiroz, M.-J. R. P.; Kirsch, G. Tetrahedron 2002, 58, 7943-7949.

4. (a) Baudoin, O.; Guénard, D.; Guéritte, F. J. Org. Chem. 2000, 65, 9268-9271; (b) Baudoin, O.; Cesario, M.; Guénard, D.; Guéritte, F. J. Org. Chem. 2002, 67, 1199-1207.

5. Typical procedure for the BSC reaction: A dry Schlenk tube was charged under $\mathrm{Ar}$ with the 6-bromobenzo[b]thiophene 1a or $\mathbf{1 b}(1 \mathrm{mmol})$ in dioxane $(2-3 \mathrm{~mL}), \mathrm{Et}_{3} \mathrm{~N}$ (4 equiv.), $\mathrm{Pd}(\mathrm{OAc})_{2} \quad(5 \mathrm{~mol} \%)$, 2-(dicyclohexylphosphino)biphenyl $(20 \mathrm{~mol} \%)$ and pinacolborane (3 equiv.) and the mixture was heated at $80^{\circ} \mathrm{C}$ for $1 \mathrm{~h}$. After cooling, water $(2-3 \mathrm{~mL})$, the substituted 2-bromonitrobenzene $(0.7$ equiv.) and $\mathrm{Ba}(\mathrm{OH})_{2} \cdot 8 \mathrm{H}_{2} \mathrm{O}$ (3 equiv.) were added, and the solution was heated at $100^{\circ} \mathrm{C}$ for $90 \mathrm{~min}$. After cooling, water and $\mathrm{CH}_{2} \mathrm{Cl}_{2}$ were added. The phases were separated, the aqueous phase was extracted with more $\mathrm{CH}_{2} \mathrm{Cl}_{2}$ and the organic phase was dried $\left(\mathrm{MgSO}_{4}\right)$ and filtered. Removal of the solvent gave a brown solid which was submitted to column chromatography using solvent gradient from neat petrol to $10 \%$ ether/petrol to give compounds $\mathbf{2}$ as solids which were recrystallized from ether/petrol.

2a isolated yield: $80 \%$; yellow crystals, $\mathrm{mp} 186-188^{\circ} \mathrm{C}$; found: $\mathrm{C}, 66.12 ; \mathrm{H}, 5.49 ; \mathrm{N}, 4.31 ; \mathrm{S}, 9.98 \%$, calcd for $\mathrm{C}_{18} \mathrm{H}_{17} \mathrm{NO}_{3} \mathrm{~S}: \mathrm{C}, 66.04 ; \mathrm{H}, 5.23 ; \mathrm{N}, 4.28 ; \mathrm{S}, 9.79 \% ; \delta_{\mathrm{H}}(300$ $\left.\mathrm{MHz}, \mathrm{CDCl}_{3}\right) 2.27\left(\mathrm{~s}, 3 \mathrm{H}, \mathrm{CH}_{3}\right), 2.32\left(\mathrm{~s}, 3 \mathrm{H}, \mathrm{CH}_{3}\right), 2.52$ $\left(\mathrm{s}, 3 \mathrm{H}, \mathrm{CH}_{3}\right), 3.94\left(\mathrm{~s}, 3 \mathrm{H}, \mathrm{OCH}_{3}\right), 7.13(\mathrm{~d}, 1 \mathrm{H}, 5-\mathrm{H}, J 8$ $\mathrm{Hz}), 7.18\left(\mathrm{dd}, 1 \mathrm{H}, 5^{\prime}-\mathrm{H}, J 8\right.$ and $\left.3 \mathrm{~Hz}\right), 7.28\left(\mathrm{~d}, 1 \mathrm{H}, 6^{\prime}-\mathrm{H}\right.$, $J 8 \mathrm{~Hz}), 7.46$ (d, 1H, 4-H, $J 8 \mathrm{~Hz}), 7.52$ (d, 1H, 3'- $\mathrm{H}, J 3$ $\mathrm{Hz}) ; \delta_{\mathrm{C}}\left(75.4 \mathrm{MHz}, \mathrm{CDCl}_{3}\right) 11.49\left(\mathrm{CH}_{3}\right), 13.87\left(\mathrm{CH}_{3}\right)$, $18.06\left(\mathrm{CH}_{3}\right), 55.90\left(\mathrm{OCH}_{3}\right), 108.66(\mathrm{CH}), 118.61(\mathrm{CH})$, $118.91(\mathrm{CH}), 125.37(\mathrm{CH}), 127.84(\mathrm{C}), 128.51(\mathrm{C}), 129.28$ (C), $131.82(\mathrm{C}), 133.49(\mathrm{CH}), 135.00$ (C), 138.92 (C), 140.52 (C), 149.87 (C), 159.02 (C). 
2b isolated yield: $70 \%$; orange crystals, mp $162-164^{\circ} \mathrm{C}$; found: C, 59.18; $\mathrm{H}, 4.01 ; \mathrm{N}, 3.77 ; \mathrm{S}, 9.04 \%$, calcd for $\mathrm{C}_{18} \mathrm{H}_{14} \mathrm{~F}_{3} \mathrm{NO}_{2} \mathrm{~S}: \mathrm{C}, 59.17 ; \mathrm{H}, 3.86 ; \mathrm{N}, 3.83 ; \mathrm{S}, 8.77 \% ; \delta_{\mathrm{H}}$ $\left(300 \mathrm{MHz}, \mathrm{CDCl}_{3}\right) 2.29\left(\mathrm{~s}, 3 \mathrm{H}, \mathrm{CH}_{3}\right), 2.33\left(\mathrm{~s}, 3 \mathrm{H}, \mathrm{CH}_{3}\right)$, $2.54\left(\mathrm{~s}, 3 \mathrm{H}, \mathrm{CH}_{3}\right), 7.12(\mathrm{~d}, 1 \mathrm{H}, 5-\mathrm{H}, J 8 \mathrm{~Hz}), 7.51(\mathrm{~d}, 1 \mathrm{H}$, 4-H, $J 8 \mathrm{~Hz}), 7.57$ (d, 1H, 6'-H, $J 8 \mathrm{~Hz}), 7.90(\mathrm{dd}, 1 \mathrm{H}$, $5^{\prime}-\mathrm{H}, J 8$ and $\left.2 \mathrm{~Hz}\right) 8.26\left(\mathrm{~d}, 1 \mathrm{H}, 3^{\prime}-\mathrm{H}, J 2 \mathrm{~Hz}\right)$.

2c isolated yield: $50 \%$; yellow crystals, $\mathrm{mp} 203-205^{\circ} \mathrm{C}$; found: $\mathrm{C}, 60.01 ; \mathrm{H}, 4.51 ; \mathrm{N}, 3.78 ; \mathrm{S}, 8.36 \%$, calcd for $\mathrm{C}_{19} \mathrm{H}_{16} \mathrm{~F}_{3} \mathrm{NO}_{2} \mathrm{~S}: \mathrm{C}, 60.15 ; \mathrm{H}, 4.25 ; \mathrm{N}, 3.69 ; \mathrm{S}, 8.45 \% ; \delta_{\mathrm{H}}$ $\left(300 \mathrm{MHz}, \mathrm{CDCl}_{3}\right) 2.23\left(\mathrm{~s}, 3 \mathrm{H}, \mathrm{CH}_{3}\right), 2.50\left(\mathrm{~s}, 3 \mathrm{H}, \mathrm{CH}_{3}\right)$, $2.54\left(\mathrm{~s}, 3 \mathrm{H}, \mathrm{CH}_{3}\right), 2.74\left(\mathrm{~s}, 3 \mathrm{H}, \mathrm{CH}_{3}\right), 6.82(\mathrm{~s}, 1 \mathrm{H}, 5-\mathrm{H})$, $7.55\left(\mathrm{~d}, 1 \mathrm{H}, 6^{\prime}-\mathrm{H}, J 8 \mathrm{~Hz}\right), 7.89$ (broad d, 1H, 5'-H, J 8 Hz), 8.25 (broad s, 1H, 3'-H).

6. Ferreira, I. C. F. R.; Queiroz, M.-J. R. P.; Kirsch, G. Tetrahedron 2003, 59, 975-981.

7. Typical procedure for reductive cyclization: A dry Schlenk tube was charged under Ar with compound 2a-c (0.4 mmol) and triethyl phosphite $(1.5 \mathrm{~mL})$ and the mixture was heated at $160^{\circ} \mathrm{C}$ for $3 \mathrm{~h} 30$. The excess of triethyl phosphite was removed after a work-up with water, extractions with chloroform and evaporation on the oil vacuum pump. The oil obtained was submitted to crystallization from petrol to give compound 3 . 3a isolated yield: $70 \%$; colourless crystals, mp $220-222^{\circ} \mathrm{C}$; found 295.10339, calcd for $\mathrm{C}_{18} \mathrm{H}_{17} \mathrm{NOS} 295.10307 ; \delta_{\mathrm{H}}(300$ $\left.\mathrm{MHz}, \mathrm{CDCl}_{3}\right) 2.34\left(\mathrm{~s}, 3 \mathrm{H}, \mathrm{CH}_{3}\right), 2.55\left(\mathrm{~s}, 3 \mathrm{H}, \mathrm{CH}_{3}\right), 2.98$ $\left(\mathrm{s}, 3 \mathrm{H}, \mathrm{CH}_{3}\right), 3.92\left(\mathrm{~s}, 3 \mathrm{H}, \mathrm{OCH}_{3}\right), 6.85-6.90(\mathrm{~m}, 2 \mathrm{H}, 6$ and 8-H), 7.37 (s, 1H, 4-H), 7.90 (broad s, 1H, N-H), 8.08 (d, $1 \mathrm{H}, 9-\mathrm{H}, J 9 \mathrm{~Hz}) ; \delta_{\mathrm{C}}\left(75.4 \mathrm{MHz}, \mathrm{CDCl}_{3}\right) 11.81\left(\mathrm{CH}_{3}\right)$, $14.20\left(\mathrm{CH}_{3}\right), 18.63\left(\mathrm{CH}_{3}\right), 55.58\left(\mathrm{OCH}_{3}\right), 94.51(\mathrm{CH})$, $99.18(\mathrm{CH}), 107.33(\mathrm{CH}), 117.45(\mathrm{C}), 120.11(\mathrm{C}), 123.04$ $(\mathrm{CH}), 124.63$ (C), 127.13 (C), 130.99 (C), 133.15 (C), 138.69 (C), 138.84 (C), 141.98 (C), 158.46 (C).

3b isolated yield: $40 \%$; colourless crystals, $\mathrm{mp} 248-250^{\circ} \mathrm{C}$; found: $\mathrm{C}, 64.81 ; \mathrm{H}, 4.36 ; \mathrm{N}, 4.22 ; \mathrm{S}, 9.56 \%$, calcd for $\mathrm{C}_{18} \mathrm{H}_{14} \mathrm{~F}_{3}$ NOS: C, 64.85; H, 4.23; N, 4.20; S, 9.62\%; $\delta_{\mathrm{H}}$ $\left(300 \mathrm{MHz}, \mathrm{CDCl}_{3}\right) 2.36\left(\mathrm{~s}, 3 \mathrm{H}, \mathrm{CH}_{3}\right), 2.57\left(\mathrm{~s}, 3 \mathrm{H}, \mathrm{CH}_{3}\right)$, $3.04\left(\mathrm{~s}, 3 \mathrm{H}, \mathrm{CH}_{3}\right), 7.47(\mathrm{~s}, 1 \mathrm{H}, 4-\mathrm{H}) 7.51(\mathrm{dd}, 1 \mathrm{H}, 8-\mathrm{H}, J$ 8 and $1 \mathrm{~Hz}) 7.68(\mathrm{~d}, 1 \mathrm{H}, 6-\mathrm{H}, J 1 \mathrm{~Hz}), 8.15($ broad s, $1 \mathrm{H}$, $\mathrm{N}-\mathrm{H}), 8.29$ (d, 1H, 9-H, $J 8 \mathrm{~Hz})$

3c isolated yield: $60 \%$; colourless crystals, $\operatorname{mp~} 251-253^{\circ} \mathrm{C}$; found: $\mathrm{C}, 65.66 ; \mathrm{H}, 4.74 ; \mathrm{N}, 4.06 ; \mathrm{S}, 9.13 \%$, calcd for $\mathrm{C}_{19} \mathrm{H}_{16} \mathrm{~F}_{3} \mathrm{NS}$ : C, 65.69; H, 4.64; N, 4.03; S, 9.23\%; $\delta_{\mathrm{H}}(300$ $\left.\mathrm{MHz}, \mathrm{CDCl}_{3}\right) 2.54\left(\mathrm{~s}, 3 \mathrm{H}, \mathrm{CH}_{3}\right), 2.62\left(\mathrm{~s}, 3 \mathrm{H}, \mathrm{CH}_{3}\right), 2.93$ (s, $3 \mathrm{H}, \mathrm{CH}_{3}$ ), 3.02 (s, 3H, $\left.\mathrm{CH}_{3}\right), 7.49$ (broad d, $1 \mathrm{H}, 8-\mathrm{H}, J$ $8 \mathrm{~Hz}) 7.72$ (broad s, 1H, 6-H), 8.10 (broad s, 1H, N-H), $8.29(\mathrm{~d}, 1 \mathrm{H}, 9-\mathrm{H}, J 8 \mathrm{~Hz})$. 